\title{
Family Matters: Peter Canisius as Confessor and Spiritual Guide in Early Modern Augsburg. A Case Study
}

\author{
Simone Laqua-O'Donnell \\ University of Birmingham \\ S.LaquaODonnell@bham.ac.uk
}

\begin{abstract}
After Peter Canisius's arrival in the bi-confessional city of Augsburg in 1559, he quickly succeeded in winning over a large number of converts to the Catholic Church through his impressive abilities as a preacher and confessor. One of his most remarkable successes was the conversion of Ursula Fugger, a member of the influential Fugger dynasty and a devout Protestant. This article examines the pastoral relationship that developed between Peter Canisius and Ursula Fugger as well as her family. It also analyzes the specific strategies developed by Canisius and his fellow Jesuits for guiding the different genders and generations belonging to this important Augsburg family.
\end{abstract}

\section{Keywords}

Augsburg - Peter Canisius - Ursula Fugger - conversion - exorcism - patronage triple contract - pastoral relationship - gender - generations

The imperial city of Augsburg officially became bi-confessional in the 1550 os. With a population of around 35,000, it housed a Lutheran majority and a Catholic minority of around 7,000 within its walls. To support the Catholic cause, Bishop Otto Truchseß von Waldburg (1514-1573) invited Peter Canisius (1520-1597), one of the most prolific Jesuits, to preach in the city. From the beginning, there was substantial resistance from the Protestant guilds, the secular clergy, and the cathedral canons, against allowing the Jesuits entry into 
the city. ${ }^{1}$ The antagonism towards the Society of Jesus only increased with the arrival of Canisius in 1559. Bishop Truchseß von Waldburg and Canisius had first met at the imperial diet at Worms in 1545, and had kept in contact ever since. In their letters, they discussed the foundation of a university at Dillingen, not far from Augsburg, the importance of the printing press, how to advance Catholicism in the German lands and other matters of religious and theological consequence. Waldburg also lobbied for Canisius to become permanent cathedral preacher at Augsburg. Canisius, though slightly less enthusiastic about the exertions connected to such a position, also saw the strategic advantages of this location for the Society in the German lands. From 1559 onwards, he began to preach at the cathedral and gave many popular sermons in Latin and German in front of large crowds. His oratorical talents helped to strengthen Catholic sentiment in Augsburg and won many converts. In his first year alone, he is said to have converted six hundred men and women. ${ }^{2}$ The most famous of these converts were Ursula von Lichtenstein and Sibylla von Eberstein. Although Protestant, both women had married into the Catholic Fugger family. The Fuggers belonged to the city's elite, and were one of the wealthiest and most prominent merchant families of the sixteenth century. Early supporters of the Society of Jesus, they felt that the fathers would help to preserve Catholicism in the city. ${ }^{3}$

The conversions were the beginning of a particularly close relationship between the Society of Jesus and the Fuggers. This relationship encompassed men, women, children, and even servants. Based on the critical edition of Canisius's correspondence edited by Otto Braunsberger, this article will focus on the pastoral relationship between Peter Canisius and Ursula Fugger. Ursula had been a member of the Augsburg elite since her marriage in 1542. She was also a newcomer to Catholicism and therefore had to be taught how to be Catholic by the man who had converted her in the first place. Every soul mattered, but for Canisius Ursula's was of particular importance because as a Fugger she had a preeminent role in the propagation of the new post-Tridentine Catholicism in the area. A priority in this relationship therefore lay in teaching Ursula and her family how to be good Catholics, of the kind that the Society and the post-Tridentine church wanted to see. This was embattled territory after all.

1 Georg Lutz, Marx Fugger (1529-1597) und die Annales Ecclesiastici des Baronius (Sora: Centro di studi sorani "V. Patriarca," 1982), 424-545, here 476.

2 Ibid.

3 Ibid., 481. 
By becoming a confessor to the Fuggers, Canisius developed close ties with one of the most influential families of early modern Europe. Their influence was built on their banking and mercantile interests, and encompassed civic as well as imperial and papal politics. This pastoral relationship could therefore lead the Society into contentious territory reflecting the tension between religion, politics, ethics, profit, and patronage. Although Ignatius of Loyola himself had supported the involvement of the Society as confessors to the elites, ${ }^{4}$ the Jesuits struggled to define the right balance between religion and politics. How could they ensure that the advantages gained from this service outweighed the ill-will and suspicion that such privileged access inevitably generated? In 1602, after several general congregations had tried to resolve this tension, Superior General Claudio Acquaviva released his Instruction for Confessors of Princes, which stipulated norms about the confessor's personal conduct at court. ${ }^{5}$ Above all, Acquaviva declared, the confessor was to avoid the appearance of exercising political power. The aim was to separate matters of conscience from matters of politics-a near impossible feat when there had to be considerable overlap between the two.

As a woman, Ursula Fugger was not supposed to hold any direct political power, so such entanglements of religion and politics might seem to be of little relevance to her pastoral relationship with Canisius. Ursula's place was, after all, firmly anchored in her family and household. Much of Canisius's time was accordingly spent on the seemingly mundane rather than on high politics. However, this article will argue that advice on the profane, such as on child rearing, marital alliances, career choices, business and the conduct of trade was key to the successful confessor-lay relationship, not only because these

4 "All members of the body participate in the welfare of the head, and all subjects in the welfare of the prince, and so we ought to esteem the spiritual assistance that we give to these [princes] more highly than the assistance that we provide others." Ignatius Loyola to Diego Mirón, Feb. 1, 1553, Obras completas de San Ignacio de Loyola (Madrid: Editorial Católica, 1963), 803-6, cited in Robert Bireley, The Jesuits and the Thirty Years War: Kings, Courts, and Confessors (Cambridge: Cambridge University Press, 2003), 27. Later Ignatius formalized this view in the Constitutions: the Society should endeavor "to retain the benevolence of the Apostolic See, which the Society should especially serve; and then that of the temporal rulers and noble and powerful persons whose favor or disfavor does much toward opening or closing the gate to the service of God and the good of souls." Ignatius also summoned the Jesuits "to abstain as far as possible from all secular employments," and especially political matters. Ignatius of Loyola, The Constitutions of the Society of Jesus, trans. by George E. Ganss, SJ (St. Louis: The Institute of Jesuit Sources, 1970), no. 823-24; 337.

5 For example, the court confessor was to live in a Jesuit community and was not to frequent the court regularly but to wait until he was summoned. 
everyday issues mattered hugely to the identity and self-perception of the urban elites but also because they shaped their religious outlook and devout practice. This article analyses the specific strategies developed by Canisius and his fellow Jesuits for guiding different genders and generations and for making their Augsburg mission a success, measurable by the amount of financial and social patronage they received.

Because Canisius did not shy away from involvement in the daily interactions of the family, he had a unique position among the Fuggers. He was not a brother, nor a relative or friend, but his manner of conducting this spiritual relationship gave him precious access to the life and mind of Ursula and of her household. Examining the relationship between the Jesuits and the Fuggers allows us to apply the concept of gender on a truly relational basis: between people of different genders, generations, and social status.

\section{The Reformation in Augsburg}

On the eve of the Reformation, Augsburg hosted at least twenty-five churches, chapels, and cloisters of various orders for men and women. Some churches were also adjoined by preaching houses (Predigthäuser) that served the lay population with special sermons on Sundays and feast days. These preaching houses were some of the earliest sites of evangelical preaching in the city. ${ }^{6}$ Although Christoph von Stadion, prince-bishop of Augsburg (1478-1543), had originally supported humanist-trained preachers in the city, he later attempted to hinder evangelical reform until he was forced to leave the city by the Protestant church ordinance. The Protestant reformation found many early supporters in Augsburg, as in other imperial cities. ${ }^{7}$ The evangelical message reached Augsburg through a potent mix of the spoken and the printed word. After Wittenberg, Augsburg was the second most important center of printing for Luther's writings during the early Reformation. In 1518, Luther came to

6 Michele Zelinsky Hanson, Religious Identity in an Early Reformation Community: Augsburg 1517 to 1555 (Leiden: Brill, 2009), 12.

7 On the Reformation in Augsburg, see Horst Jesse, Die Geschichte der Evangelischen Kirche in Augsburg (Pfaffenhofen: W. Ludwig Verlag, 1983); Philip Broadhead, "Guildsmen, Religious Reform and the Search for the Common Good:The Role of the Guilds in the Early Reformation in Augsburg," Historical Journal 39, no. 3 (1996): 577-97; Friedrich Roth, Augsburgs Reformationsgeschichte, 4 vols. (Munich: Ackerman, 1901-11); Josef Kirmeier, Wolfgang Jahn, and Evamaria Brockhoff ed., “... wider Laster und Sünde”: Augsburgs Weg in die Reformation (Cologne: Haus der Bayerischen Geschichte, 1997). 
Augsburg to submit himself to an interrogation by Cardinal Legate Cajetan in the Fugger palace, which added to his popularity in the city. By the early $1520 s$, the evangelical movement had gained a significant following, particularly amongst urban craftsmen. Some of his popularity might have rested in the fact that Luther criticized the large trading companies, like the Fuggers. He felt that their high profits went against the principle of the common good, and asked in his tract To the Christian Nobility of the German Nation (1520) for the authorities to put "a bridle into the mouth of the Fuggers and similar companies." Jakob Fugger and his relatives remained unimpressed by the message of the reformers. Raymund Fugger, Jakob's nephew, even provoked public outrage with derogatory remarks about the new teachings. ${ }^{9}$

Initially, the city council tried to steer a moderate policy characterized by tolerance towards both Protestantism and Catholicism. This seemed only reasonable considering the religious split of the city's elite and Augsburg's close ties to the emperor and the other nearby Catholic princes. However, in 1534, the city gave in to popular demand and introduced Protestantism and by January 1537 the Reformation was complete. All Catholic clerics were now dismissed, mass was prohibited, all monasteries were dissolved, and a church ordinance was introduced, as well as a new moral and police ordinance. ${ }^{10}$ In the aftermath of the introduction of the Reformation, the Fuggers were largely ousted from political office. However, not all was lost. The Fuggers continued to retain close business and political contacts with several prominent Protestant families. The city did not want to alienate one of its most influential families. In 1538, they were inducted into the patriciate, the city's highest social order, and in the 1540 s they were elected to political office again. After 1555, when the city officially became bi-confessional with the Peace of Augsburg, the Fuggers once again emerged as powerful supporters of Catholicism, which culminated in the generous financial patronage they gave for the foundation of a Jesuit college in the city. ${ }^{11}$

8 On the Fuggers and the evangelical movement: Mark Häberlein, The Fuggers of Augsburg: Pursuing Wealth and Honour in Renaissance Germany (Charlottesville: University of Virginia Press, 2012), 181-91.

9 Die Chroniken der deutschen Städte vom 14. bis zum 16. Jahrhundert, 5 vols. (reprinted Göttingen: Vandenhoeck u. Ruprecht, 1966), 25, 204.

10 See Häberlein, The Fuggers, $186-87$.

11 "A sum of 30,000 florins came from the estate of Christoph Fugger, and the brothers Octavian Secundus and Philipp Eduard donated eight houses worth 12,00o florins to the Society. The college, which started instruction in 1582 , was built on this site. In 1586 , the college received another 16,00o florins from the Fugger family and twelve years later, Hans Fugger's son Christoph donated 40,00o florins for its maintenance." Ibid., 193. 
Although the Fuggers were known to be staunch Catholics, they were open to confessional compromise where it was expedient. For this reason, Marx Fugger (1529-1597) and his brother Georg (1518-1569) both married Protestant women, as did some other members of the family. ${ }^{12}$ Mixed marriages were not uncommon in the bi-confessional city. In 1580, during his stay in Augsburg, Michel de Montaigne (1533-1592) observed that they were a daily occurrence with the party more eager for the match taking on the confession of their marriage partner. ${ }^{13}$ That does not mean, of course, that the Society of Jesus endorsed them. Because both Fugger men married before Canisius took up his position as cathedral preacher, he could not prevent the unions. He could, however, attempt to convert the Protestant partners to Catholicism. After all, conversions were a lifelong specialty of his.

\section{Conversions}

While converting members of the influential Fuggers to Catholicism was advantageous in itself, it could have an important multiplying effect. In 1551, when Canisius stayed in Vienna, he succeeded in converting a large number of people after he had first won over a number of noble ladies. ${ }^{14}$ In 1561 , Wilhelm Elderen, a fellow Jesuit who lived with Canisius in Augsburg, reported that "Peter Canisius has a very rich harvest [of converts]. About this the Church is happy. The converts are people of not modest origin." ${ }^{15}$ In the same year, he wrote to Superior General Diego Laínez about "a big growth in Catholics such as has not been achieved in Augsburg for many years. The work of the Jesuits has not only turned simple folk from heretics to Catholics but many wealthy and noble people too."16 The significance attributed to winning over people of high status also fitted the principles laid down by Ignatius himself in his Constitutions:

For that reason, the spiritual aid, which is given to important and public persons, ought to be regarded as more important, since it is a more

\footnotetext{
12 Other Fugger converts were Elisabeth Nothafft von Weißenstein (1539-1582), wife of Hans Fugger, and Jakob Graf von Montfort (d. 1573), the husband of Katharina Fugger.

13 Michel de Montaigne, Tagebuch einer Badereise (Stuttgart: Steingrüben, 1963), 95.

14 Paul Drews, Petrus Canisius: Der erste deutsche Jesuit (Halle: Verein für Reformationsgeschichte, 1892), 39 .

15 Otto Braunsberger, ed., Beati Petri Canisii, Societatis Iesu, epistulae et acta (Freiburg im Breisgau: Herder Verlag, 1896-1923), 3:226 [henceforth PCE].

$16 \quad P C E, 3: 232$.
} 
universal good. This is true whether these persons are laymen such as princes, lords, magistrates, or ministers of justice, or whether they are clerics such as prelates. The same also holds true of the spiritual aid which is given to persons distinguished for learning and authority, because of that reason of its being the more universal good. For that same reason, too, preference ought to be shown to the aid, which is given to the great nations such as the Indies, or to important cities, or to universities, which are generally attended by numerous persons who by being aided themselves can become laborers for the help of others. ${ }^{17}$

Rather unflatteringly, Canisius attributed his success in converting women to the "usual weakness, loquaciousness, and exaggerations of Eve's daughters [...]. Varium enim ac mutabile semper femina."18 At Augsburg, his most famous converts were Ursula von Lichtenstein (?-1573), wife of Marx Fugger, and her sister-in-law Sibylla von Eberstein (1531-1589), wife of Marx's brother Georg. Describing Ursula Fugger's conversion to Bishop Otto von Waldburg, Canisius wrote: "In the beginning Georg Fugger's wife was hostile to the Catholics. But now, that I have repeatedly spoken to her from one soul to another, she loves us very much."19 By giving Ursula individual pastoral attention and appealing directly to her soul, Canisius was able to make her see the true religion. Once won over, she quickly became more devout and involved than most Catholics around her:

She often guides her whole household to the sacraments, makes every effort to win over converts, whom she supports and strengthens in their faith. I would almost call her house a convent, because she holds prayers with her family that often. Indifferent to her own high standing and her honor, she spends her time giving alms, she donates jewelry to the church and the altar and works with her own hands on vestments and other things for the glory of the house of God. She makes sure her daughters do the same, and with them makes clothes and linen for the poor. Whereas before she rarely went to church for many weeks, now she spends a few hours every day there and never misses a feast-day service despite the long way to the cathedral. ${ }^{20}$

\footnotetext{
17 Ignatius of Loyola, Constitutions, no. $622 \mathrm{~d}$, e.

18 James Brodrick, Petrus Canisius, 1521-1579 (Vienna: Herder Verlag, 1950), 2:248.

19 PCE, 3:268.

20 Ibid.
} 
The advantages of winning such an enthusiastic recruit are clear. Her fervor and piety were in themselves impressive and gave Canisius much satisfaction. "Ursula is making great strides in her piety and [...] shows herself to be more religious than any other woman here in Augsburg."21 She led by example through her devotion to the Catholic faith and her pious works, making those around her follow her lead and turning the whole Fugger household into a deeply religious community, prompting Canisius to compare her home to a convent.

After her conversion, Ursula Fugger remained in close contact with the Jesuits for the remainder of her life. She entrusted herself to Canisius's advice and the Jesuit, in his role as her confessor, became her guide on matters spiritual and worldly. Such intimate confessional relationships were not uncommon and became a feature of the Catholic Reformation when the post-Tridentine church placed greater emphasis on the sacrament of penance. ${ }^{22}$ For Canisius, this spiritual relationship was not without its challenges and tribulations: a difficult balance between professional distance and friendly intimacy had to be struck. Success depended on both parties' adherence to prescribed gender roles: as her spiritual director, Canisius had to remain in control, dispense advice, and, if necessary, correct Ursula's behavior; the woman at the receiving end of his guidance was to listen and learn, behave modestly, and adhere to his direction. Not an easy feat to achieve for someone who in her daily interaction commanded respect and obsequiousness. In order to meet these demands, Canisius relied on traditional perceptions of gender. He framed Ursula as a mother: "Christ sent her to us like a mother for the good of the many."23 In communications between members of the Society, Ursula's open-handed support is explained in these terms too: "she loves the society wonderfully and like a mother loves her sons." ${ }^{24}$ Using the image of motherhood allowed the Jesuits to accept the almost passionate support they received from women without damaging the respect in which the order was held - an order which had decided to concede women only an external role when it rejected the foundation of a female branch of "Jesuitesses." 25 Fittingly, a mother was supposed to be giving

\section{$21 \quad P C E, 4: 1055$.}

22 As Olwen Hufton has pointed out, this is also a story about women: elite women in particular demonstrated an enthusiasm for sacramental confession that far outstripped that of their male counterparts. Olwen Hufton, The Prospect before Her: A History of Women in Western Europe, 1500-180o (London: Harper Collins, 1995), 365.

23 PCE, 2:445.

24 Ibid., 2:181.

25 John W. O'Malley, The First Jesuits (Cambridge, MA: Harvard University Press, 1993). For examples of some women who aspired to the Jesuit active apostolate, such as Angela 
and selfless, making sacrifices without expecting much in return. While the Jesuits were full of admiration for Ursula Fugger's religious devotion, her "sons," the recipients of her wonderful love, certainly appreciated the benefits that her social position, her connections, her wealth, and her zeal afforded the Society. ${ }^{26}$ Using the language of motherhood was also meant to protect the Jesuits from accusations of improper behavior between director and directed. It signaled that this was not a dangerous relationship between a man and a woman, but rather one between a mother and her son, caring but harmless.

The Society received numerous gifts from Ursula Fugger. Once, when Canisius reported to Rome about a Jesuit novice who had absconded, he also confessed that the boy had taken two hundred Goldtaler that Ursula had gifted to him.. ${ }^{27}$ The correspondence between the Jesuit college in Munich and Rome also shows that Ursula could be relied upon to respond positively and generously to any request for financial support. ${ }^{28}$ In their correspondence, Canisius and his fellow Jesuits often recalled her generosity and praised her devotion to the Catholic cause. There is even a reference to her as "sanctissima et clarissima matrona." It can be assumed that the writer knew that the term "sanctissima" was usually only used with reference to canonized saints. ${ }^{29}$ While the Jesuits were obviously deeply grateful for Ursula's pious efforts, at times they could not hide a sense of frustration. This became especially apparent when they were forced to deal with some cases of demoniacal possession in the Fugger households.

\section{Exorcising Evil}

From 1568 onwards, there was a strong increase in cases of possession in the city. ${ }^{30}$ Initially only performed within the walls of private houses, later large

Merici and Mary Ward, see Elizabeth Rapley, The Dévotes: Women and Church in Seventeenth-century France (Montreal: McGill-Queen's University Press, 1990); also Laurence Lux-Sterritt, "Mary Ward's English Institute and Prescribed Female Roles in the Early Modern Church," in Redefining Gender, Catholicism and Spirituality: Women and the Roman Catholic Church in Britain and Europe, 1200-19oo, ed. Laurence Lux-Sterritt and Carmen Mangion (Basingstoke: Palgrave MacMillan, 2010), 83-98.

$26 \quad P C E, 6: 913$.

27 Ibid., 5:641.

28 Martha Schad, Die Frauen des Hauses Fugger von der Lilie (15--17.Jahrhundert): AugsburgOrtenburg-Trient (Tübingen: Mohr, 1989), 37.

29 Ibid

$30 \quad$ Paul von Stetten d. Ä., Geschichte des Heiligen Römischen Reichs Freyen Stadt Augspurg (Frankfurt-Leipzig: Merz \& Mayer, 1743-58), 82. 
crowds would gather to witness exorcisms in churches and public places. The Jesuits, and especially Canisius, performed many of these ritualistic spectacles. When a fierce polemical war between Protestants and Catholics about the issue unfolded, the city council decided to ban public exorcisms in 1568 to preserve the peace. In the wake of this decision, Canisius decided to move the performance of exorcisms to the shrine of Altötting outside of Augsburg. In the same year, a first exorcism was performed in the household of Ursula Fugger on a possessed servant girl called Katharina. In another case, a servant girl was possessed by an evil spirit and publicly admitted that she had killed her illegitimate child. Nothing more is said about the case in the sources but it would be fascinating to know what Canisius thought about the alleged propensity of these women of low status to attract evil spirits. Did he draw conclusions about their morality or piety? How did he explain that, overall, women were more prone to be possessed than men? Or did he interpret these cases against the background of the larger confessional and religious struggles of the time? ${ }^{31}$

What emerges quite clearly from the sources is a sense of uneasiness on the part of the Jesuits about the issues of possession and exorcism, which existed even at the highest level of the order. Ignatius of Loyola had never himself participated in an exorcism and Diego Laínez was mistrustful of the practice. Canisius was often criticized for his activities in this regard. Superior General Francisco de Borja ordered him not to get too involved because the "procedure does not fit what we do" and took away valuable time from other important things. ${ }^{32}$ A palpable discomfort about the issue and about performing exorcisms in high-profile households like the Fuggers' can also be read in the report that was sent by the German provincial Paul Hoffaeus to Borja:

As soon as I had arrived in Augsburg, the women [Ursula and her sisterin-law Sibylla von Eberstein] came to me with bold requests and tears [...]; they reported about the possessed women in their household and asked if Father Wendelin could look after them [...]. I gave my permission for him to do so but only in secret and only once a week and never at

31 Lyndal Roper argues that between 1560 and 1580 there was an "exorcism mania" in Augsburg and that exorcisms served confessional purposes as a propaganda tool in religiously divided territories. Lyndal Roper, Oedipus and the Devil: Witchcraft, Sexuality and Religion in Early Modern Europe (London: Routledge, 1994), especially ch. 8: "Exorcism and the Theology of the Body."

32 Bernhard Duhr, Geschichte der Jesuiten in den Ländern deutscher Zunge im XVI.Jahrhundert (Freiburg im Breisgau: Herder Verlag, 1907), 732. 
night and only for so long as it takes to get your response telling me if we are to continue with this. ${ }^{33}$

Rather than staging the usual public spectacle, Wendelin was ordered to perform the ritual of exorcism behind closed doors and in broad daylight. The Jesuits, it seems, were anxious not to make themselves easy targets for Protestant accusations of improper behavior and mockery about Catholic superstitious beliefs. Even more aggravating in this matter was Ursula Fugger's (heretical) belief in a kind of transmigration of souls, wherein the souls of the dead could migrate into the bodies of the living. It seriously alarmed Canisius that one of his most ardent followers should harbor such theologicallyunsound views. And what was worse, he could not shake her out of them:

Ursula (and the other Fugger [Johannes]) want to talk to you [Francisco de Borja] about their visions and miracles, I have explained to Ursula your opinion about these matters [...] but I can see that whatever we say regarding these matters does not have much impact. We are afraid that in this regard they lack the necessary humility and wisdom and they need a more appropriate confessor. ${ }^{34}$

The Jesuit could not prevent his frustration from spilling on to the page because he was not able to convince Ursula to change her views. Running up against a wall of female ignorance, Canisius even began to question his role as her spiritual director. Borja replied poste-haste with the following advice: "The good will of the Fuggers must be retained [...] if Frau Fugger cannot be made to listen [...], she has to submit herself to the Pope's judgment." ${ }^{35}$ Worried about losing the goodwill of these powerful patrons, Borja saw only one way forward. Ursula Fugger had to be convinced by the most powerful man in all of Christendom: the pope.

Meanwhile, another case of possession occurred in the family. Susanna Roschmann, a Protestant servant girl, exhibited signs of possession, including eating glass. After the Jesuits had attempted to save her for two years, Ursula decided to go on a pilgrimage to Rome. Thus, in September 1569, Ursula, Johann Fugger, and Susanna set out on their journey, accompanied by their exorcist. The Jesuit fathers in Augsburg were not happy with this initiative. In a fit of impatience with his pastoral sheep, Canisius wrote: "Those Fuggers

$\begin{array}{ll}33 & P C E, 6: 1677 . \\ 34 & \text { Ibid. } \\ 35 & P C E, 6: 1679 .\end{array}$


already demand enough attention whether present or not [...]; it should be arranged that Frau Ursula returns home soon to look after her family" and cautioned the superior general against giving the Fuggers too much attention. ${ }^{36}$ Agreeing with that advice, Hoffaeus warned Borja in Rome that "Frau Ursula and Herr Johannes are very skilled at persuasion and pull their confessor in any direction they like."37 After their arrival in the city, the pilgrims were welcomed in audiences with the pope and Augsburg's absent bishop, Cardinal Truchseß von Waldburg. The pope arranged for several Jesuits to exorcise Susanna, and after a few attempts in the church of S. Maria dell'Anima, the spirits fled her body in March 1570. With the young girl cured, the Fuggers returned to Augsburg. From now on, Ursula took on the responsibility of educating Susanna in the Catholic faith.

Throughout, the relationship between Ursula Fugger and the Jesuits swayed between honest admiration and irritation about her self-confident manner: "Some princes and people here and in Bavaria feel very much offended, because in spiritual matters Frau Ursula does not listen to anyone in Germany but prefers to go to Rome for a piece of advice [...]. They call her a very haughty mind." ${ }^{38}$ Her stubbornness was seen as a trait especially unbecoming in a woman. In addition, Ursula was also described as "good at persuasion" and even manipulative. This criticism only surfaced when the Jesuits in Augsburg were unhappy that their star convert, previously characterized as pious and charitable, had broken the gender mold and revealed rather too much independence of mind and action.

\section{Bringing Up a New Generation}

"She [Ursula] raised her children in such a manner that they seemed more knowledgeable in piety and arts than school." ${ }^{39}$ This judgment about the education of the Fugger children shows how much Georg and Ursula valued the religious education of their children. That piety and religion were an integral part of a good upbringing in early modern Europe is not surprising. However, for the Fugger children this was not only meant to turn them into exemplary Christians but also to shape their future in a more practical manner: at least

\footnotetext{
$36 \quad$ Ibid., 1683 .

37 Ibid.

38 Ibid., 1693 .

39 Ibid., 3:272.
} 
four of the fourteen siblings were supposed to join a religious order. ${ }^{40}$ Ursula's eldest daughter, Sidonia Isabella (1543-1601), was meant to become a nun but got married instead. Ursula's eldest sons, Philipp Eduard (1546-1618) and Octavian Secundus (1549-1600), were also prepared to join an order; and in the case of Octavian the negotiations with the Society of Jesus were pursued to an advanced stage before being aborted for good in $1570 .{ }^{41}$ Only her daughter Anna Jacobäa (1547-1587) was given to the Dominicans. Although ultimately Ursula's wish of raising a Jesuit "recruit" did not materialize, the influence of the order on the upbringing of her sons and daughters was considerable.

From 1564 onwards, the Fuggers entrusted the education of their eldest boys to the Jesuits by sending first Philipp then Octavian to study at the Collegium Germanicum in Rome. In a letter to his superior, Canisius positively underlined that it was on Ursula's initiative that her sons were sent there. ${ }^{42}$ "Father Canisius delivered your letter," wrote Borja in 1565 to Ursula Fugger, "which is testimony to your usual charity and piety [...]; and he also brought your donation in support of our order, which comes at the right time [...]; that you and your husband, your children and the whole Fugger family want to be in our prayers will happen with pleasure; we owe it to you and thank God that two of your sons, who are resident at the Collegium Germanicum, show the same character, so that we are full of hope that they will display great piety and virtue." ${ }^{\text {43 }}$ Ursula Fugger regularly asked Canisius for his advice on spiritual issues "and other things to keep the family in good form [um die Familie richtig beisammen zu halten]."44 In that she was not alone. Her husband, too, appreciated Canisius's opinion about the upbringing of his children. The future of these children was of course arranged with careful deliberation. The plan for Octavian to join the Jesuits was discussed with the Society for over seven years. This was partly due to Octavian's hesitant response to the idea. In 1566, Canisius informed the superior general that he had spoken to "Frau Fugger about her son Octavian, and she has promised to give her response in writing and to examine his determination."45 But Octavian continued to be difficult. "Frau Fugger asked me to write in a letter to her son Octavian that he cannot leave

\footnotetext{
40 During their thirty-one years of marriage, Georg and Ursula Fugger had fourteen children: eight sons and six daughters. Six died before the age of thirteen. Schad, Die Frauen, 39. For more information on the life of Octavian Secundus, see Norbert Lieb, Octavian Secundus Fugger (1549-16oo) und die Kunst (Tübingen: J.C.B. Mohr, 1980).

$42 \quad P C E, 4: 956$.

43 Ibid., 826.

44 Ibid., 1055 .

45 Ibid., 1344.
} 
[questions] about his desire and plan about [becoming a Jesuit] without an answer."46 Octavian now began to play for time. "Octavian has replied to his mother that he can only reach a decision in Augsburg. I am only little satisfied with this." ${ }^{47}$ Canisius, it seems, suspected a problem and was not happy that the Fugger son wanted to return home before giving his answer. To achieve the outcome desired by the adults, Canisius advised the parents to put pressure on Octavian. "Octavian will receive a letter from his parents admonishing him not to think about leaving [the college] but to prepare himself for the clerical life $[\ldots]$ and to submit himself wholly to the orders of the Fathers." 48 The boy's parents and Canisius had clearly formed a united front against the stubborn child. Canisius did not hesitate to exert considerable force, even if indirectly, to achieve the goal he and his patrons held in common. Although Octavian continued to be hesitant for another two years, in the end he budged. In 1569, Canisius informed Rome: "Octavian Fugger has decided to join the clerical life and wants to do so immediately. [...] We are happy that he has come to his senses after his parents treated him so hard." ${ }^{9}$ The happiness was short-lived. Only a few months later, Octavian's parents withdrew their support for the arrangement, because "they do not believe he will stay in the Society" 50

Anna Jacobäa's wishes were not met with so much consideration. At the age of thirty-five, Anna Jacobäa wrote to her brothers detailing her reasons for fleeing the Dominican convent where she had lived for over two decades. She explained how much she had suffered from the forced separation from home at the age of thirteen, saying that she had not become a nun out of her own free will. According to Anna Jacobäa's account, Canisius had played a pivotal role in her forced vocation. He "used many words and craftiness [...] to persuade a young thirteen-year-old." In 1561, she then joined a convent "to please her mother." When she changed her mind after six months, Canisius reminded her "with harsh words" of her duties towards her parents. ${ }^{51}$ Anna Jacobäa's admission to the convent had been the fulfillment of a dream for Ursula Fugger, and had been pursued with the forceful support of Peter Canisius, quite in contrast to the spirit of his own words: "Parents, who force their sons either to marry or to live chastely or to join a monastery behave sinfully."52 Although, curiously,

\begin{tabular}{ll}
\hline 46 & Ibid., 1386. \\
47 & Ibid., 1389. \\
48 & Ibid., 1525. \\
49 & Ibid., 1632. \\
$5^{0}$ & Ibid. \\
$5^{1}$ & Ibid., 3:272. \\
$5^{2}$ & Ibid.
\end{tabular}


Canisius had not included daughters into this admonition, he was of course aware of the church's prohibition of forced admissions.

Life in the convent might have been bearable while the women were allowed regular interaction with their families. But after 1563, Canisius lobbied the prioress of the convent as well as the emperor for the strict implementation of enclosure in accordance with the decrees of Trent. Henceforth, no personal contact between the members of the convent and their families was permitted, and an iron grille through which the sisters had communicated with the outside world was walled up.

Finally, in 1582 , the opportunity arose to flee the convent. Next to her habit, Anna Jacobäa is said to have left a note which read: "Got allain die ehr, in dise kutten komb ich nicht mehr [Only God alone deserves honor; this habit will never be worn by me again]. ${ }^{\prime 53}$ In her letter to her brothers a sense of indignation and pain about her treatment can clearly be discerned. Anna Jacobäa complained about her mother's religious zeal and about the Jesuits' influence over her, but also described her brothers' lack of interest in her well-being. It is clear that the wishes and feelings of a young girl were sacrificed and the needs of an adult woman ignored to have one member of the Fugger family given to the service of God. Anna Jacobäa's disillusionment with the religion of her family was so great that she converted to Protestantism. After her dramatic escape from the Dominican convent of St. Catherine in Augsburg, she married Count Heinrich viI von Ortenburg, much to the disapproval of her brothers Georg, Octavian, and Anton. Twenty years after Anna Jacobäa was first forced to pledge lifelong virginity, she reversed that decision and married a Protestant, creating quite a scandal in her town.

\section{Usurious Business?}

In 1576, the relationship between the Jesuits and the Fuggers turned sour. The reason was a longstanding difference of opinion that touched the core of the Fugger identity as merchants and businessmen. At issue was Canisius's campaign against the so-called triple contract, according to which an investor could obtain five percent interest without risk. Canisius had first preached against the practice in 1560 but over time he became firmer in his views. He regarded the practice of taking interest in general as sinful and finally decided 
not to absolve Catholics who participated in this business. ${ }^{54} \mathrm{He}$ was met by a storm of protest. The disappointed and angry words that Marx Fugger wrote to his Jesuit confessor, Theobald Stotz, captured an opinion common amongst the city's Catholic merchant population:

In the future, I will spare you and the Society from my confession; and I will not burden the Society of Jesus with other things any more either. I would be happy, though, and would give much for the knowledge that I had not wasted all my efforts for the Jesuits: because that offended a lot of people and nothing was gained through my efforts. [...] If we paid attention to the rule you advise [not to take any interest] it would mean that within three years the house of Fugger and the whole of Germany would sink into abysmal poverty. That would of course not have to worry the Pope or the Society of Jesus. It would be altogether good if you could arrange for money to be given to me without interest, for I owe approximately 1.5 million Gulden for which I must pay 5.8 or even ten percent. Against this, the King of Spain owes me one million and neither pays me interest nor returns the principal. What ought I to do now? 55

Not only the Fuggers but also other patrician families, the cathedral chapter, and the city council positioned themselves in opposition to Canisius's views. That does not mean the Fuggers did not care for his opinion. Fearing for the souls of her family, Ursula Fugger repeatedly asked the Jesuits to get further clarification on the matter from the pope. She also sent a letter to Borja for advice. This communication was signed in her own hand from "Your and Your Society of Jesus's docile servant and obedient daughter Ursula Fuggerin." ${ }^{56}$ As the exchange between the Jesuits and the Fuggers over the years has shown, both sides relied on existing gender stereotypes to advance their communication. When the Jesuits praised Ursula Fugger's generosity, she was called a mother. When she was requesting advice or special favors from those at the top of the Jesuit hierarchy, it was prudent to assume the position of a spiritual daughter and servant of the Society. In this she was not alone. Other women (for example, Teresa of Ávila and Jeanne de Chantal) habitually relied on

\footnotetext{
54 Bernhard Duhr, "Die deutschen Jesuiten im 5\%-Streit des 16. Jahrhunderts," Zeitschrift für katholische Theologie 24 (1900): 209-48.

55 Lutz, Marx Fugger, 485 .

56 Braunsberger, $P C E, 5: 626$ and 628 .
} 
gendered language, proclaiming themselves as the weaker sex, to advance important relationships with the men around them. ${ }^{57}$

To unburden her conscience, Ursula performed penitential exercises, supported the plans for the Jesuit college, and carried out even more charitable works. ${ }^{58}$ Still concerned, she turned to the Jesuits for advice on how to help the soul and conscience of her husband- "about whom she worries with reason," stated Canisius. ${ }^{59}$ Superior General Borja replied to her that not every business conducted by the Fuggers was usurious, although some of it was; a diplomatic but ambiguous answer if ever there was one. Their provincial interpreted his words as a cautious endorsement of Canisius's position and advised that the laity should look for a new confessor if they were unhappy with this stance. 60 Although Borja's response did not bring the matter to a conclusion, in writing to Ursula he revealed how great his appreciation of this generous benefactress was: not many women at the time would have commanded sufficient esteem to be considered worthy of such a privilege.

\section{Conclusion}

Ursula Fugger was a deeply pious woman and a truly enthusiastic supporter of the Jesuits. She was also an influential multiplier of her faith, as well as a crucial intermediary to her husband Georg Fugger. The Jesuits knew how precious this was and made sure that they cultivated a relationship with both husband and wife. But the influence that the Jesuits gained over the Fuggers also created serious conflict with the cathedral chapter. The canons complained that the Fugger women's religious enthusiasm, as kindled by the fathers, interfered too much with ordinary parish life. ${ }^{61}$ Within the Fugger family all was not well either. In her will of 1567 , Ursula wanted to leave all her jewelry to the Jesuits. Her relatives vetoed this plan and insisted that her treasures should remain in the family. To appease Ursula, it was decided that she would be given 250 florins each year. After her death, the accumulated sum would be given to the Society

57 See for example Ruth Manning, "A Confessor and His Spiritual Child: François de Sales, Jeanne de Chantel, and the Foundation of the Order of the Visitation," Past and Present, Supplement 1 (2006): 101-17; Alison Weber, Teresa of Ávila and the Rhetoric of Femininity (Princeton: Princeton University Press, 1990).

58 Schad, Die Frauen, 36.

59 PCE, 4:1055.

6o Lutz, Marx Fugger, 589 .

$61 \quad P C E, 4: 1134$. 
together with an additional 4,00o florins. Although this added up to a very handsome sum, it could not quite compare with the estimated value of her jewelry $(14,883$ florins). We do not know who exactly had opposed her original intention, but it is clear that the family worried about her generosity towards the Jesuits.

Overall, Canisius enjoyed good relations with the Fuggers. He supported Georg and Ursula with advice and helped them through their daily life with spiritual direction. The children perhaps felt his presence most when it came to their education. But whereas the boys received letters in which Canisius encouraged them in their educational progress, the girls were given much less sympathetic treatment. If Anna Jacobäa's account is to be believed, she was made to join a convent through force and threats. Canisius was instrumental in this, too. In his dealings with the Fugger family, Canisius followed the predominant gender conventions of the time: high respect was given to the parents and the boys were also treated with regard; the girls, however, received much less consideration.

This analysis of the pastoral relationship between Peter Canisius and Ursula Fugger also shows the difficult balance that had to be struck between the director and his spiritual daughter on the one hand and between the order and a powerful patroness on the other. To balance the demands that propriety prescribed for both situations was not always an easy task and required diplomacy. For the sake of winning souls on this missionary battleground and to further the advancement of the Society, the Jesuits were willing to put up with many a demand. Still, as is indicated in internal communications about their relationship with the Fuggers, it was not always easy to distinguish between rider and horse. 